\title{
Analysis of chemotaxis in Dictyostelium
}

\author{
Huaqing Cai, Chuan-Hsiang Huang, Peter N. Devreotes, and Miho lijima* \\ Department of Cell Biology, Johns Hopkins University, School of Medicine, 107 Hunterian 107, \\ 725 N. Wolfe St., Baltimore, MD, 21205. Phone: (410) 502-6836
}

\begin{abstract}
Dictyostelium discoideum is an excellent model organism for the study of directed cell migration since Dictyostelium cells show robust chemotactic responses to the chemoattractant cAMP. Many powerful experimental tools are applicable, including forward and reverse genetics, biochemistry, microscopy, and proteomics. Recent studies have demonstrated that many components involved in chemotaxis are functionally conserved between human neutrophils and Dictyostelium amoebae. In this section, we will describe how to define the functions of proteins that mediate and regulate cell motility, cell polarity, and directional sensing during chemotaxis in Dictyostelium.
\end{abstract}

\section{Introduction}

Chemotaxis is a dynamic process that involves directional sensing, cell polarity, and cell motility. Cells continuously rearrange their cytoskeleton and plasma membrane, resulting in an asymmetric cell shape, and periodically extend pseudopods. Actin polymerization in pseudopods at the leading edge of the cell is synchronized with contractile forces generated by myosin motor proteins at the rear. A directional sensing system biases pseudopodia formation towards the source of the chemoattractant and thus orients cell movement along the extracellular chemical gradient. To understand the molecular mechanisms of chemotaxis, a variety of assays have been used to dissect the individual sub-reactions involved in Dictyostelium.

This model organism is an excellent system for the study of cell migration. The molecular mechanisms underlying chemotaxis, such as actin polymerization, intracellular signaling, and cell migration, are highly conserved among eukaryotes. Therefore many powerful experimental tools used to dissect these processes in other organisms are applicable to Dictyostelium. When there are sufficient nutrients Dictyostelium cells proliferate as haploid single amoebae; however, when nutrients are depleted starvation immediately triggers the developmental program for surviving harsh conditions through spore formation. Chemotaxis plays an essential role in Dictyostelium development. During differentiation, 100,000 cells migrate toward aggregation centers that release the chemoattractant cAMP and form multicellular structures. Differentiating cells secrete cAMP every 6 min and waves of extracellular cAMP reinforce the expression of the cAMP receptors and other signaling molecules that are required to respond to cAMP.

Differentiation normally takes several hours and the chemotactic ability peaks at 5-6 hrs after starvation. Around this time, cells establish an increased cell polarity due to downregulation of basal cytoskeletal activity and become highly sensitive to chemoattractant stimulation. Thus, the developing amoebae display robust and rapid chemotactic responses.

Correspondence: miijima@jhmi.edu.

8 To compare sample loading, stain the membrane with Coomassie Brilliant Blue solution for a few minutes, destain for suitable amounts of time, and finally rinse with $\mathrm{H}_{2} \mathrm{O}$ briefly. Let the membrane dry at room temperature. 
In this chapter, we will describe how Dictyostelium mutants can be analyzed to determine whether and how they are defective in chemotaxis. Cell movement toward chemoattractants can be examined by direct observation using time-lapse microscopy. Quantification of cell movement and shape provides information on cell polarity, directionality, and rate of cell migration. In addition, the many biochemical reactions involved in chemotaxis can be examined in mutant and wildtype cells. Assays for chemoattractant-receptor interactions, Gprotein activation, phosphatidylinositol $(3,4,5)$-triphosphate $\left(\mathrm{PIP}_{3}\right)$ production and activation of Tor complex 2 (TorC2) and Ras signaling are described in this chapter. It should be noted that these biochemical reactions are often localized and therefore it is critical to determine where the reactions occur using microscopic approaches in addition to biochemical measurements. These assays will reveal the molecular mechanisms underlying chemotaxis and the function of proteins involved in this process. Identification of genes that are mutated in chemotaxis-defective mutants will help us understand the function of proteins involved in chemotaxis.

\section{Materials}

\subsection{Cell culture and Development}

1. HL5 medium, $\mathrm{pH}$ 6.5: $10 \mathrm{~g} / \mathrm{L}$ Dextrose, $10 \mathrm{~g} / \mathrm{L}$ Proteose pepton, $5 \mathrm{~g} / \mathrm{L}$ Yeast extract, $0.67 \mathrm{~g} / \mathrm{L} \mathrm{Na} 2 \mathrm{HPO}_{4} 7 \mathrm{H}_{2} \mathrm{O}, 0.34 \mathrm{~g} / \mathrm{L} \mathrm{KH}_{2} \mathrm{PO}_{4}$. Autoclave and store at room temperature. $10 \mathrm{mg} / \mathrm{mL}$ Streptomycin sulfate.

2. DB (Development Buffer), pH 6.5: $5 \mathrm{mM} \mathrm{Na}_{2} \mathrm{HPO}_{4}, 5 \mathrm{mM} \mathrm{KH}_{2} \mathrm{PO}_{4}, 2 \mathrm{mM}$ $\mathrm{MgSO}_{4}, 0.2 \mathrm{mM} \mathrm{CaCl}_{2}$.

3. DB agar: $1 \%$ agar in DB.

4. $\mathrm{PM}$ (Phosphate magnesium buffer), $\mathrm{pH}$ 6.5: $5 \mathrm{mM} \mathrm{Na}_{2} \mathrm{HPO}_{4}, 5 \mathrm{mM} \mathrm{KH}_{2} \mathrm{PO}_{4}, 2$ $\mathrm{mM} \mathrm{MgSO}_{4}$

5. cAMP: $10 \mathrm{mM}$ stock solution. Store at $-20^{\circ} \mathrm{C}$.

6. Caffeine: $100 \mathrm{mM}$ stock solution. Store at $-20^{\circ} \mathrm{C}$.

7. Hydrophobic agar: $1 \%$ agar in $\mathrm{dH}_{2} \mathrm{O}$.

\subsection{Time-Lapse Imaging}

1. Inverted fluorescence microscope.

2. Lab-Tek II chambered coverglasses (Nalge Nunc).

3. FemtoJet Microinjector (Eppendorf).

4. Femtotips microcapillary pipettes (Eppendorf)

5. Micromanipulator (Eppendorf, Narushige).

6. The image processing software NIH ImageJ

\subsection{G Protein Activation}

1. Latrunculin A: $1 \mathrm{mM}$ stock solution in DMSO. Stored at $-20^{\circ} \mathrm{C}$.

2. Alexa Fluor 594 (Molecular Probe): $10 \mathrm{mM}$ stock solution. Stored at $-20^{\circ} \mathrm{C}$.

3. Inverted fluorescence microscope capable of: (1) excitation at $457 \mathrm{~nm}$ and simultaneous recording for emissions at $480 \mathrm{~nm}$ and $535 \mathrm{~nm}$ (for FRET). For example, we use an Olympus IX 71 inverted microscope with a 60X, 1.45 NA objective, a Kr/Ar laser line, and the Dual-View system (Optical Insights, LLC) 
mounted to a Photometrics Cascade 512B CCD for simultaneous image acquisition. (2) excitation at $550-600 \mathrm{~nm}$ and emission around $600-650 \mathrm{~nm}$ (for Alexa 594). A DsRed fluorescence filter set is used for Alexa 594 fluorescence.

\section{4 $\mathrm{PIP}_{3}$ Production}

1. DB-MES, pH 6.5: $20 \mathrm{mM}$ MES, $2 \mathrm{mM} \mathrm{MgSO}_{4}, 0.2 \mathrm{mM} \mathrm{CaCl}_{2}$.

2. $\left[{ }^{32} \mathrm{P}\right]$ Phosphorus $(5 \mathrm{mCi} / \mathrm{mL}, \mathrm{NEX})$.

3. TLC plate (EM Science).

4. Nucleopore filter membrane (Whatman)

5. Plastic cup (VWR)

\subsection{TorC2-PKB Activity}

1. Mouse anti-phospho PDK docking motif monoclonal antibody (Cell Signaling). Use 1:2,000 dilution in TBST containing 5\% (w/v) BSA; detect with anti-mouse IgG-HRP.

2. Rabbit anti-phospho PKC (pan) monoclonal antibody (Cell Signaling). Use 1:2,500 dilution in TBST containing 5\% (w/v) BSA; detect with anti-rabbit IgG-HRP.

3. Rabbit anti-phospho PKB substrate monoclonal antibody (Cell Signaling). Use 1:2,500 dilution in TBST containing 5\% (w/v) BSA; detect with anti-rabbit IgGHRP.

\subsection{GST-RBD-Byr2 Pull Down Assay}

1. GST-RBD-Byr2 expression construct(1).

2. BL21 (DE3) Escherichia coli competent cells. Store at $-80^{\circ} \mathrm{C}$.

3. $\mathrm{LB}$ (Luria broth): $10 \mathrm{~g} / \mathrm{L} \mathrm{NaCl}, 10 \mathrm{~g} / \mathrm{L}$ tryptone, $5 \mathrm{~g} / \mathrm{L}$ yeast extract. Adjust $\mathrm{pH}$ to 7.0 with $\mathrm{NaOH}$. Autoclave and store at room temperature.

4. Ampicillin. $100 \mathrm{mg} / \mathrm{mL}$, filter-sterilize. Store at $-20^{\circ} \mathrm{C}$.

5. IPTG (isopropyl- $\beta$-D-thiogalactoside). $1 \mathrm{M}$ stock solution. Store at $-20^{\circ} \mathrm{C}$.

6. DTT (dithiothreitol). $1 \mathrm{M}$ stock solution. Store at $-20^{\circ} \mathrm{C}$.

7. PMSF (phenylmethylsulphonyl fluoride). $100 \mathrm{mM}$ stock solution. Dissolve in isopropanol. Store at $-20^{\circ} \mathrm{C}$.

8. Lysozyme. $10 \mathrm{mg} / \mathrm{mL}$. Store at $-20^{\circ} \mathrm{C}$.

9. Glutathione sepharose $4 \mathrm{~B}$. Store at $4^{\circ} \mathrm{C}$.

10. $10 \times$ PBS (Phosphate-buffered saline), $\mathrm{pH} 7.5: 1.37 \mathrm{M} \mathrm{NaCl}, 27 \mathrm{mM} \mathrm{KCl}, 18 \mathrm{mM}$ $\mathrm{KH}_{2} \mathrm{PO}_{4}, 100 \mathrm{mM} \mathrm{Na} 2 \mathrm{HPO}_{4}$. Store at $4{ }^{\circ} \mathrm{C}$.

11. Suspension buffer: $1 \times$ PBS, $1 \mathrm{mM}$ DTT, $1 \mathrm{mM}$ PMSF. Add DTT and PMSF before use.

12. $2 \times$ Lysis buffer: $20 \mathrm{mM}$ sodium phosphate ( $\mathrm{pH} 7.2), 300 \mathrm{mM} \mathrm{NaCl}, 1 \% \mathrm{NP}-40$, $20 \%$ glycerol, $1 \mathrm{mg} / \mathrm{mL}$ BSA, $20 \mathrm{mM} \mathrm{MgCl} 2,2 \mathrm{mM}$ EDTA, $2 \mathrm{mM} \mathrm{Na}_{3} \mathrm{VO}_{4}, 10$ $\mathrm{mM} \mathrm{NaF}$, with one tablet of protease inhibitor (Roche complete) per $25 \mathrm{~mL}$.

13. Wash buffer: $10 \mathrm{mM}$ sodium phosphate ( $\mathrm{pH} 7.2$ ), $150 \mathrm{mM} \mathrm{NaCl}, 0.5 \% \mathrm{NP}-40$, $10 \%$ glycerol, $10 \mathrm{mM} \mathrm{MgCl} 2,1 \mathrm{mM}$ EDTA. 
14. Antibodies: Mouse monoclonal anti-pan Ras antibody Ras10 (Calbiochem), and anti-mouse IgG-conjugated HRP. Store at $4^{\circ} \mathrm{C}$.

\section{Methods}

\subsection{Assays for Chemotactic Responses}

Upon starvation, Dictyostelium cells initiate development into fruiting bodies. During development, Dictyostelium cells obtain the ability to chemotax toward cAMP, in order to form multilcellular structures. Therefore, it is important to develop Dictyostelium cells to make them competent for robust chemotaxis by depleting nutrients. Methods to induce development and prepare chemotaxis-competent cells are described below. When mutant cells are isolated, it is also important to analyze their developmental phenotypes as chemotaxis-defective mutants often fail to normally develop. To examine chemotaxis, two methods have been extensively used. The first assay observes chemotaxing cells toward cAMP released from a micropipette under a light microscope. The other assay analyzes cells moving toward cAMP on agar plates.

\subsubsection{Developing Cells on Agar Plates}

1. Grow cells to a density of $2-5 \times 10^{6}$ cells $/ \mathrm{mL}$ in $\mathrm{HL} 5$ medium at $22^{\circ} \mathrm{C}$, shaking at $180 \mathrm{rpm}$.

2. Centrifuge $5 \times 10^{6}$ cells at $500 \mathrm{~g}$ for $5 \mathrm{~min}$. Remove the supernatant and wash twice with $1 \mathrm{~mL}$ DB.

3. Resuspend cells in DB at $5 \times 10^{6}$ cells $/ \mathrm{mL}$ and spread $200 \mu \mathrm{L}$ of cell suspension onto a $3.5 \mathrm{~cm}$ dish containing $1 \mathrm{~mL}$ of $1 \%$ DB agar. Remove the DB after cells attach.

4. Incubate cells at $22^{\circ} \mathrm{C}$. Cells start aggregating around $6 \mathrm{hrs}$ after plating. Wildtype cells form mature fruiting bodies within $24 \mathrm{hrs}$ (Fig 1a).

\subsubsection{Prepare Chemotaxis-competent Cells}

1. Centrifuge $2 \times 10^{8}$ cells at $500 \mathrm{~g}$ for $5 \mathrm{~min}$. Remove the supernatant and wash twice with $40 \mathrm{~mL}$ DB.

2. Resuspend cells at $2 \times 10^{7}$ cells $/ \mathrm{mL}$ in $10 \mathrm{~mL}$ DB, transfer cells into a $125 \mathrm{~mL}$ flask, and shake for $1 \mathrm{hr}$ at $100 \mathrm{rpm}$.

3. Pulse cells with cAMP at a final concentration of 50-100 $\mathrm{nM}$ every 6 min for 4-5 hrs using a timer-controlled-peristaltic pump. For example, set a pump to drop 50 $\mu \mathrm{L}$ of $20 \mu \mathrm{M}$ cAMP every 6 min. Chemotaxis-competent cells start aggregating within 1 hour after cells are plated on DB agar as described in the section 3.1.1. (Developing Cells on Agar Plates).

4. To monitor the expression of developmentally regulated genes, take $100 \mu \mathrm{L}$ of samples every hour and analyze using immunoblotting with antibodies against cAMP receptor 1 (cAR1) and adenylyl cyclase (ACA) (2)(see Note 1).

\subsubsection{Needle Assay}

1. Dilute developed cells by $\sim 50$ fold in $\mathrm{DB}$ and disrupt aggregates by pipetting gently. Transfer cells $(\sim 3 \mathrm{~mL})$ to a one-well Lab-Tek II chambered coverglass, allow them to adhere to the coverglass for $10 \mathrm{~min}$, and ensure that cells are individually separated under a light microscope. 
2. Fill a micropipette with $15 \mu \mathrm{L}$ of $1 \mu \mathrm{M}$ cAMP. Attach the micropipette to a micromanipulator which is connected to a microinjector. Use a continuous injection mode with a compensation pressure (Pc) of $100 \mathrm{hPa}$. Place the micropipette in the middle of the field. Lower the micropipette till it just touches the chambered coverglasss.

3. Observe cells using light microscopy with 10 to $40 x$ objectives and take pictures every 10-30 sec for $30 \mathrm{~min}$ (Fig. 1b).

\subsubsection{Two-drop Assay}

1. Dilute developed cells by $\sim 5$ fold in DB. Spot $5 \mu \mathrm{L}$ of cell suspension and $5 \mu \mathrm{L}$ of different concentrations of cAMP $(0.1,1$, and $10 \mu \mathrm{M})$ onto a $1 \%$ hydrophobic agar. The distance between spots is $5 \mathrm{~mm}$.

2. Capture images of cells using a 20x objective every $30 \mathrm{sec}$ for $1 \mathrm{hr}$.

\subsection{Assays for Chemotactic Signalings}

3.2.1 Visualization of G Protein Activation by FRET-During development, Dictyostelium cells aggregate by migrating towards high concentrations of cAMP, which binds to the $\mathrm{G}$ protein-coupled receptor cAR1. Upon ligand binding, cAR1 activates the heterotrimeric $\mathrm{G}$ protein composed of $\mathrm{Ga} 2, \mathrm{G} \beta$, and $\mathrm{G} \delta$, causing $\mathrm{Ga} 2$ to dissociate from the G $\beta$-G $\delta$ complex. This dissociation event can be monitored by the decrease of fluorescence resonance energy transfer (FRET) between Ga 2 and G $\beta$ tagged with CFP and YFP, respectively (3). The measurement can be done either at the population level using a fluorometer, or at the single-cell level using fluorescence microscopy (4). By recording the entire spectrum of emission averaged over a large number of cells, the population approach allows more accurate estimation of the absolute FRET change. However, in most instances the kinetics of FRET change is more important than its absolute magnitude, and single-cell measurement with fluorescent microcopy is advantageous due to its ease of applying complex spatial or temporal patterns of stimulation. The following protocol describes the procedure for monitoring $\mathrm{G}$ protein FRET at the single-cell level in real time by fluorescent microscopy, with the use of a micropipette that allows rapid introduction and removal of stimulation.

\section{A. Preparation of Cells}

1. Dictyostelium cells (Ga2-null or G $\beta$-null) overexpressing both Ga2-CFP and G $\beta$ YFP are developed by cAMP pulsing as described in 3.1.2 (Prepare Chemotaxiscompetent Cells). Instead of the typical 4-5 hrs pulsing used for wildtype cells, a longer duration of pulsing (6-7 hrs) is recommended based on the observation that knock-out cells rescued with $\mathrm{G}$ proteins tagged with fluorescent proteins have delayed development.

\footnotetext{
1 A potential complication which one might encounter during analysis of chemotaxis mutants is that mutant cells show defects in differentiation. Failure in formation of multi-cellular structure is an indication for chemotaxis defects since chemotaxis is required for aggregation. However, this phenotype may simply result from defects in differentiation itself. One way to test if differentiation is affected is to examine the expression of developmentally regulated genes including cAMP receptors (cAR1) and adenylyl cyclase (ACA). If differentiation is impaired, their expression will be delayed or inhibited. If differentiation is found to be affected, one could take alternative approaches to bypass this defect and study chemotaxis. For example, mutants defective in producing cAMP, including aca-, crac-and piaA-cells, are unable to relay cAMP and therefore show developmental as well as chemotactic phenotypes. Artificial cAMP pulse mimicking the cAMP wave can help these cells to undergo differentiation and bypass the defects, allowing one to specifically examine chemotaxis in these mutants. It is also possible to analyze chemotaxis toward folate in vegetative cells since folic acid activates essentially the same downstream reactions as cAMP. Although receptors for folic acid have not yet identified and chemotactic responses to folate are relatively weaker compared to cAMP, this experiment will enable one to study chemotaxis independent of differentiation.
} 
2. Place cells on a one-well chambered coverglass as descried in 3.1.3. (A Needle Assay).

3. Cells are immobilized by the addition of Latrunculin A to a final concentration of 5 $\mu \mathrm{M}$. Typically cells lose their polarized morphology within 10 min of Latrunculin A treatment and round up. This step is to minimize the effect of changes in cell morphology on the analysis of fluorescent signal.

\section{B. Setting up Micropipettes}

1. Fill a Femtotips micropipette with $5 \mu \mathrm{L}$ of $10 \mu \mathrm{M}$ cAMP solution containing 50 nM Alexa Fluor 594. Attach the micropipette to a microinjector and micromanipulator. Set a microinjector to continuously inject cAMP with a compensation pressure $(\mathrm{Pc})$ of $100 \mathrm{hPa}$.

2. Under low magnification, use the micromanipulator to position the micropipette tip at the center of the viewing field. Save the position by holding the "position 1" button till a beeping sound is heard. Lift the micropipette $(\sim 0.5 \mathrm{~cm})$ and save the position by holding the "position 2" button till a beeping sound is heard.

3. To obtain the spatial and temporal characteristics of the applied cAMP stimulation, fill a clean Tab-TekII chamber with DB and mount over a 60x objective. Using a dsRed fluorescence filter set, acquire time-lapse movies with a frame rate of one per second while bringing the micropipette tip in (position 1) and out (position 2) of the center of the field. Typically a stable gradient is established within 10 seconds of introducing the micropipette.

\section{Microscopy and cAMP Stimulation}

1. Mount the Lab-Tek II chamber loaded with cells (step 3) over a 60x objective. Cells are excited with a 457-nm laser line, and the image of emission at $480 \mathrm{~nm}$ (CFP channel) and $535 \mathrm{~nm}$ (YFP channel) are acquired simultaneously using the Dual-View system attached to the CCD camera.

2. Look for cells with bright emissions in both channels. Adjust the position of the selected cell(s) to a suitable distance from where the tip of the micropipette will be located when introduced.

3. Take time-lapse movies with a rate of two seconds per frame. Acquire at least ten frames before introducing the micropipette.

4. Use the "position 1" and "position 2" buttons on the micromanipulator to introduce and remove the micropipette while acquiring video.

\section{Analysis of G Protein FRET Response}

1. Open the saved video files in ImageJ.

2. For each frame, measure the mean pixel values for cells in both CFP and YFP channels. In ImageJ, the mean pixel value of a selected region of interest can be calculated using the "Measure" function under "Analyze" ( see Note 2). Similarly, choose a background region to measure the mean value in both channels. Subtract the background values to obtain the corrected CFP and YFP emissions for cells.

2 Instead of measuring a selected region frame by frame manually, the process can be performed with a macro. Under Plugins, click New to open a Macro editing window and type in the following script: for (i=1; i<1000; i++) \{setSlice(i);run("Measure"); Click Ctrl $+\mathrm{R}$ to run the Macro. 
3. Plot the corrected CFP and YFP emissions as well as the YFP/CFP ratio over time. Upon cAMP stimulation, CFP emissions should increase and YFP decrease. The YFP/CFP ratio should decrease and is usually more robust than either CFP or YFP emission because it is corrected for the frame-to-frame noise in excitation intensity (see Note 3). A typical result is shown in Fig. 2.

3.2.2 Detection of $\mathrm{PIP}_{3}$ Production-In chemotaxing cells, $\mathrm{PIP}_{3}$ is locally produced and activates signaling events that lead to actin polymerization at the leading edge. Pleckstrin homology $(\mathrm{PH})$-domain-containing proteins that bind to $\mathrm{PIP}_{3}$ are highly localized at the front of chemotaxing cells and mediate downstream events. The PH-domaincontaining proteins include CRAC (5), PKB (6) and PhdA (7). The production of $\mathrm{PIP}_{3}$ is regulated by PI3-kinase (PI3K) and PI3-phosphatase (PTEN). PI3K phosphorylates $\mathrm{PI}(4,5) \mathrm{P}_{2}$ to produce $\mathrm{PIP}_{3}$. On the other hand, PTEN converts $\mathrm{PIP}_{3}$ to $\mathrm{PI}(4,5) \mathrm{P}_{2}$. Both PI3K and PTEN are required for $\mathrm{PIP}_{3}$ production and chemotaxis toward cAMP in Dictyostelium (8-10). Here, we describe methods to measure $\mathrm{PIP}_{3}$ production and localization upon cAMP stimulation. For in vivo analysis, GFP fused the PH domain of CRAC is used to visualize $\mathrm{PIP}_{3}$ by fluorescence microscopy (5-11). Amounts of $\mathrm{PIP}_{3}$ can be quantitatively analyzed by extracting lipids from cells.

\section{A. Time-lapse Imaging of $\mathrm{PIP}_{3}$ Production in Response to Chemoattractant Stimulation}

1. Prepare chemotaxis-competent cells expressing GFP-PHcrac as described in the section 3.1.2 (Prepare Chemotaxis-comptent Cells).

2. Resuspend the cells in $\mathrm{DB}$ at $\sim 5 \times 10^{5}$ cells $/ \mathrm{mL}$. Place $360 \mu \mathrm{L}\left(\sim 2 \times 10^{5}\right.$ cells $)$ in a well of 8 -well chambered coverglasss. Allow the cells to adhere for $10 \mathrm{~min}$.

3. Place the chamber on an inverted fluorescence microscope.

4. Stimulate cells by adding $40 \mu \mathrm{L}$ of $10 \mu \mathrm{M}$ cAMP to the chamber. Carefully squirt cAMP solution to avoid disturbing the cells.

5. Capture images of cells using a 40x objective every 3 seconds for $1 \mathrm{~min} . \mathrm{PIP}_{3}$ production peaks in the plasma membrane at 5-10 sec after stimulation (Fig. 3a).

\section{B. In Vivo Translocation of PHcrac}

1. Prepare chemotaxis-competent cells expressing GFP-PHcrac.

2. Basalate cells by adding caffeine at a final concentration of $2-5 \mathrm{mM}$ and shake for $20 \mathrm{~min}$ at $200 \mathrm{rpm}$.

3. Centrifuge cells at $500 \mathrm{~g}$ for $5 \mathrm{~min}$ at $4^{\circ} \mathrm{C}$. Remove the supernatant. Wash cells twice with $40 \mathrm{~mL}$ ice-cold PM.

4. Resuspend cells in $2.5 \mathrm{~mL} \mathrm{PM}$ at $8 \times 10^{7}$ cells $/ \mathrm{mL}$ and keep them on ice until used in the assay.

5. Aliquot cells into small plastic cup and shake at $200 \mathrm{rpm}$.

6. Add cAMP at a final concentration of $1 \mu \mathrm{M}$ (e.g. $15 \mu \mathrm{L}$ of $100 \mathrm{mM}$ cAMP into 1.5 $\mathrm{mL}$ of cells).

\footnotetext{
${ }^{3}$ Since YFP can be directly excited to a smaller extent by $457 \mathrm{~nm}$, YFP emission is not entirely the result of FRET. Due to variations in expression levels of Ga2-CFP and G $\beta$-YFP from cell to cell, however, it is not possible to determine the absolute magnitude of FRET at the single cell level only from emissions at $480 \mathrm{~nm}$ and $535 \mathrm{~nm}$. Instead, the changes in the intensity of CFP and YFP emissions as well as the YFP/CFP ratio are used as surrogates for FRET changes.
} 
7. Take samples at $0,5,20,60,120$ and $180 \mathrm{sec}$ as described below.

a. Lyse $200 \mu \mathrm{L}$ cells through $5 \mu \mathrm{m}$ nucleopore filter into $1 \mathrm{~mL}$ ice-cold PM.

b. Spin at maximum speed for $1 \mathrm{~min}$ at RT in microcentrifuge.

c. Remove the supernatant.

d. Resuspend the pellet with $50 \mu \mathrm{L}$ of $1 \mathrm{x}$ Sample Buffer.

8. Analyze $5 \mu \mathrm{L}$ samples using SDS-PAGE and immunoblotting with anti-GFP antibodies (Fig. 3b).

\section{Detection of $\mathrm{PIP}_{3}$ by Lipid Extractions and TLC}

1. Prepare chemotaxis-competent cells in DB-MES.

2. Wash twice with $40 \mathrm{~mL}$ ice-cold DB-MES. Resuspend cells at $8 \times 10^{7}$ cells $/ \mathrm{mL}$ in DB-MES.

3. Aliquot $1.5 \mathrm{~mL}$ cells into a small plastic cup and shake at $200 \mathrm{rpm}$

4. Add $150 \mu \mathrm{L}$ of $5 \mathrm{mCi} / \mathrm{mL}^{32} \mathrm{Pi}$ ( $5 \mathrm{mCi}$ Phosphorus $\mathrm{P} 32$ radio neucleotide: $\mathrm{NEX}$ ) at a final concentration of $500 \mu \mathrm{Ci} / \mathrm{mL}$ and incubate cells for $40 \mathrm{~min}$.

5. Basalate cells by adding $50 \mu \mathrm{L}$ of $0.1 \mathrm{M}$ caffeine, and shake at $200 \mathrm{rpm}$ for $20 \mathrm{~min}$.

6. Wash cells twice and resuspend in $1.5 \mathrm{~mL}$ ice-cold DB-MES.

7. Shake cells in a small plastic cup at $200 \mathrm{rpm}$ and stimulate with $1 \mu \mathrm{M}$ cAMP.

8. Take $150 \mu \mathrm{L}$ of samples at $0,5,20,60,120$ and $180 \mathrm{sec}$ into a glass tube containing $1 \mathrm{~mL}$ ice-cold $1 \mathrm{~N} \mathrm{HCl}$ and mix well by vortexing for $5 \mathrm{~min}$.

9. Add $2 \mathrm{~mL} \mathrm{MeOH} / \mathrm{CHCl}_{3}(1: 1)$ and mix well.

10. Spin samples at $1000 \mathrm{rpm}$ at $4^{\circ} \mathrm{C}$ for $5 \mathrm{~min}$.

11. Take $1 \mathrm{~mL}$ of a lower phase and mix well with $2 \mathrm{~mL} \mathrm{MeOH} / 1 \mathrm{~N} \mathrm{HCl} \mathrm{(1:1).}$

12. Spin samples at $1000 \mathrm{rpm}$ at $4^{\circ} \mathrm{C}$ for $5 \mathrm{~min}$.

13. Take $800 \mu \mathrm{L}$ of a lower phase and dry samples in a glass tube under $\mathrm{N}_{2}$ gas.

14. Pre-run TLC plate in $2 \%$ potassium oxalate/ $\mathrm{dH}_{2} \mathrm{O}: \mathrm{MeOH}(3: 2)$ over night and dry plates in a chemical hood for $30 \mathrm{~min}$.

15. Activate the TLC plate at $100^{\circ} \mathrm{C}$ for $3 \mathrm{~min}$.

16. Resuspend dried samples in $30 \mu \mathrm{L} \mathrm{CHCl}_{3}: \mathrm{MeOH}(2: 1)$.

17. Spot $10 \mu \mathrm{L}$ of samples on the heat-activated TLC plate.

18. Run the TLC plate with $\mathrm{CHCl}_{3}$ :acetone:MeOH:acetic acid: $\mathrm{H}_{2} \mathrm{O}$ (30:12:10:9:6) for 200 min at RT.

19. Detect signals by autoradiography or phosphoimaging.

\subsubsection{TorC2-PKB Activity-Dictyostelium expresses two Protein Kinase B (PKB)}

homologs, PKBA and PKBR1. PKBA is recruited to the plasma membrane through a $\mathrm{PIP}_{3^{-}}$ specific Pleckstrin Homology $(\mathrm{PH})$ domain at the N-terminus, whereas PKBR1 is tethered to the plasma membrane via N-terminal myristoylation $(6,12)$. cAMP activates the two PKBs through phosphorylation within their hydrophobic motifs (HMs) and activation loops (ALs) via Tor complex 2 (TorC2) (13) and Phosphoinositide-Dependent Kinase (PDKs) (14), respectively. Pianissimo A (PiaA), originally isolated in a forward genetic screen for 
chemotaxis defective mutants, is now recognized as a subunit of TorC2 (15). PKB phosphorylation is significantly reduced in cells lacking PiaA (13). Together, the two PKBs mediate the phosphorylation of severeal substrates, including Talin B, PI4P 5-kinase, two RasGefs, and a RhoGap (13). PKB phosphorylation occurs at the leading edge of migrating cells and plays important roles in chemotaxis. This section describes methods to assess PKB activity using phospho-specific antibodies.

\section{A. cAMP Stimulation and Sample Preparation}

1. Prepare chemotaxis-competent cells and basalate them as described in 3.2.2.B (see Note 4).

2. Resuspend cells in $5 \mathrm{~mL} \mathrm{PM}$ at $2 \times 10^{7}$ cells $/ \mathrm{mL}$ and keep on ice until used in the assay ( see Note 5).

3. Transfer ice-cold chemotaxis-comptent cells to a $5 \mathrm{~mL}$ disposable plastic cup. Immediately add $100 \mu \mathrm{M}$ of cAMP at a final concentration of $1 \mu \mathrm{M}$ and start shaking at $200 \mathrm{rpm}$ ( see Note 6).

4. At time points of $0,10,20,30,60,90,120,180 \mathrm{sec}$, transfer $100 \mu \mathrm{L}$ cells into a microcentrifuge tube containing $50 \mu \mathrm{L} 3 \times$ SDS sample buffer, and boil the sample at $95^{\circ} \mathrm{C}$ for $5 \mathrm{~min}$.

5. Analyze samples using SDS-PAGE and immunoblotting with antibodies against phospho PDK docking motif, pan phosphor PKC, and phospho PKB substrate (see Notes 7-9) (Fig. 4).

3.2.4 Ras Activity-Dictyostelium Ras proteins are important regulators of chemotaxis. Several Ras proteins, including RasB, RasC, RasD, and RasG, are activated upon cAMP stimulation $(1,16,17)$. Activated Ras can be detected at the leading edge of cells undergoing chemotaxis (1). Two proteins, $\mathrm{PI} 3 \mathrm{~K}$ and TorC2, have been suggested to function downstream of Ras in regulating chemotaxis $(8,13,18)$. Ras binding domain (RBD) from yeast Byr2 or human Raf-1, which specifically interacts with the GTP-bound form of Ras, has been used to monitor Ras activation in Dictyostelium. The RBD of Byr2 is capable of binding to all four Ras GTPases that are activated by cAMP, whereas the RBD of Raf1 is capable of binding to RasB, RasD, and RasG, but not to RasC $(1,17)$. This section describes biochemical and real-time imaging methods to assess Ras activation. In the biochemical assay, activated Ras proteins in cell lysates are pulled down by GST fused to RBD of Byr2 and glutathione-sepharose beads. In the cell imaging assay, GFP-fused RBD from Raf1 is used to detect activated Ras in vivo.

\section{A. Preparation of GST-RBD-Byr2 Attached Beads}

1. Transform E. coli with GST-RBD-Byr2 expression construct according to the manufacturer's instruction (see Note 10).

\footnotetext{
${ }_{5}^{4}$ Caffeine inhibits the TOR kinase activity and therefore needs to be removed for measuring PKB activation.

5 If cells are not maintained on ice, they will spontaneously secrete cAMP and respond in $\sim 7 \mathrm{~min}$.

${ }_{7}^{6}$ A styrofoam rack for 50-mL conical tubes makes a convenient holder for multiple beakers.

7 The primary antibody can be kept at $4{ }^{\circ} \mathrm{C}$ in TBST containing 5\% (w/v) BSA and reused for additional one to two times.

9 As shown in Figure 4, the addition of cAMP triggers rapid phosphorylations of the HM of PKBR1 and the ALs of PKBR1 and PKBA, which peak at 30-60 sec and decline to pre-stimulus level by 2-3 min. The anti-phospho PKB substrate antibody detects a few bands before stimulation. Following cAMP stimulation, about ten new bands appear and display similar kinetics as that of PKB phosphorylation. The signals from phospho-proteins (pp)-350, 280, 200, 180,140,110, 90, and 65/67, are significantly reduced in cells lacking PKB activity, such as pkbR1- and piaA-, and are therefore considered as PKB substrates. Five of the putative PKB substrates (TalinB, GefN, GefS, PI5K, GacQ) have been identified by immunoprecipitation followed by mass spectrometry. A few of these bands (pp250, pp30, and pp23) are not PKB substrates as their phosphorylations are independent of PKB activity. They presumably contain the consensus motif RXRXXS/T that is recognized by other kinases.
} 
2. Pick up a single colony, inoculate into $50 \mathrm{~mL}$ LB with $50 \mu \mathrm{g} / \mathrm{mL}$ ampicillin, and grow overnight at $37^{\circ} \mathrm{C}$ with shaking at $250 \mathrm{rpm}$.

3. Measure OD600 of the overnight culture. Transfer into $1 \mathrm{~L}$ LB containing $50 \mu \mathrm{g} /$ $\mathrm{mL}$ ampicillin at an OD600 of 0.05 . Grow cells at $37^{\circ} \mathrm{C}$ with shaking at $250 \mathrm{rpm}$ until OD600 reaches 0.4-0.6 (see Note 11).

4. Turn the temperature of the air shaker down to $20^{\circ} \mathrm{C}$ (see Note 12).

5. Add IPTG at a final concentration of $0.5 \mathrm{mM}$ to induce protein expression. Shake the culture at $20^{\circ} \mathrm{C}$ for $18-20 \mathrm{hrs}$ (see Note 13 ).

6. Harvest the cells by centrifugation at $4,000 \mathrm{~g}$ for $10 \mathrm{~min}$ at $4^{\circ} \mathrm{C}$ ( see Note 14 .

7. Remove the supernatant. Resuspend cells in $50 \mathrm{~mL}$ suspension buffer (see Note $15)$.

8. Add $100 \mu \mathrm{g} / \mathrm{mL}$ lysozyme to cell suspension and incubate on ice for $20 \mathrm{~min}$.

9. Sonicate cells. (see Note 16).

10. Add Triton $X-100$ at a final concentration of $2 \%$ and incubate on ice for $10 \mathrm{~min}$.

11. Centrifuge at $10,000 \mathrm{~g}$ for $15 \mathrm{~min}$ at $4^{\circ} \mathrm{C}$ (see Note 17).

12. Transfer the supernatant to a $50-\mathrm{mL}$ tube and add $1 \mathrm{~mL}$ glutathione-sepharose $4 \mathrm{~B}$ (see Note 18).

13. Rotate at $4^{\circ} \mathrm{C}$ for $1 \mathrm{hr}$.

14. Spin down the sepharose by centrifuging at $500 \mathrm{~g}$ for $2 \mathrm{~min}$ at $4^{\circ} \mathrm{C}$.

15. Remove the supernatant and wash five times with $40 \mathrm{~mL}$ ice-cold $1 \times$ PBS.

16. Remove the supernatant after the final wash and add equal volume of ice-cold PBS to make a $50 \%$ slurry. Store at $4^{\circ} \mathrm{C}$ (see Note 19$)$.

17. Check GST-RBD-Byr2 production by SDS-PAGE and Coomassie Brilliant Blue staining (see Note 20).

\section{B. GST-RBD-Byr2 Pull Down}

1. Prepare chemotaxis-competent cells and basalate them as described in 3.2.2.B.

2. Wash glutathione-sepharose beads carrying GST-RBD-Byr2 three times with lysis buffer. Aliquot the beads carrying $30 \mu \mathrm{g}$ GST-RBD-Byr 2 into microcentrifuge tubes. Keep on ice until used in the assay (see Note 21).

\footnotetext{
${ }^{10}$ It is important to use E. coli strains that have low protease activity, such as BL21 or BL21 (DE3).

11 It is important to use exponentially growing cells for protein induction.

12 It usually takes 20-30 min for the air shaker to cool down. The cells continue growing during this period of time to an OD600 of $0.6-0.8$.

13 GST-RBD-Byr2 has low solubility when expressed in E. coli. Inducing protein production at $20^{\circ} \mathrm{C}$ increases the solubility.

14 Protein induction can be checked by SDS-PAGE and Coomassie Brilliant Blue staining. Mix cells ( 0.5 of OD600 unit) before and after IPTG induction with $50 \mu \mathrm{L} 1 \times$ SDS sample buffer. Load $10 \mu \mathrm{L}$ on SDS polyacrylamide gel.

${ }_{15}$ Cell suspension can be frozen at $-80^{\circ} \mathrm{C}$ at this stage. When used later, thaw the cell suspension and add fresh $1 \mathrm{mM}$ PMSF.

16 Place the tube containing the cell suspension in an ice-filled plastic cup to keep the sample cool. Sonicate for $30 \mathrm{sec}$ 6-8 times with 30 -sec intervals until cells are completely lysed.

17 It is optional to filtrate the supernatant with $0.45 \mu \mathrm{m}$ filter attached to a $60 \mathrm{~mL}$ syringe. Two or three filters may be required because the filters tend to get clogged.

18 Glutathione-sepharose 4B is stored in $20 \%$ ethanol. Before use, wash three times with $10 \mathrm{~mL}$ PBS.

19 GST-RBD-Byr2 sepharose beads can also be stored in PBS $/ 50 \%$ glycerol at $-20^{\circ} \mathrm{C}$ and are usually stable for a few months.

20 Use BSA or any quantified protein as a control.

21 The volume of the beads containing $30 \mu \mathrm{g}$ GST-Byr2-RBD should be between 10-20 $\mu \mathrm{L}$.
} 
3. Resuspend basalated cells at $4 \times 10^{7}$ cells $/ \mathrm{mL}$ and keep on ice.

4. Transfer $3 \mathrm{~mL}$ cells to a $10 \mathrm{~mL}$ disposable plastic cup. Immediately add $100 \mu \mathrm{M}$ of cAMP to a final concentration of $1 \mu \mathrm{M}$ and shake at $200 \mathrm{rpm}$.

5. At time points of $10,20,40,60 \mathrm{sec}$, transfer $350 \mu \mathrm{L}$ cells into a microcentrifuge tube containing $350 \mu \mathrm{L}$ ice-cold $2 \times$ lysis buffer. Quickly mix by inverting the tube a few times and put the tube back on ice.

6. For the time point of $0 \mathrm{sec}$, mix $350 \mu \mathrm{L}$ unstimulated cells with $350 \mu \mathrm{L} 2 \times$ lysis buffer.

7. Clarify the lysate by centrifugation at $15,000 \mathrm{~g}$ for $10 \mathrm{~min}$ at $4^{\circ} \mathrm{C}$.

8. As a total cell lysate control, take $50 \mu \mathrm{L}$ of the supernatant and mix with $25 \mu \mathrm{L} 3 \times$ SDS sample buffer. Heat the sample at $95^{\circ} \mathrm{C}$ for $5 \mathrm{~min}$.

9. Transfer the remaining supernatant $(\sim 600 \mu \mathrm{L})$ to the microcentrifuge tube containing GST-RBD-Byr2 beads.

10. Rotate for $45 \min$ at $4^{\circ} \mathrm{C}$.

11. Centrifuge at $2,000 \mathrm{~g}$ for $30 \mathrm{sec}$ at $4^{\circ} \mathrm{C}$.

12. Remove the supernatant carefully. Wash beads four times with $1 \mathrm{~mL}$ wash buffer.

13. After the final wash, carefully aspirate the supernatant and add $3 \times$ SDS sample buffer. Quickly move the tubes to a heat-block that is set to $95^{\circ} \mathrm{C}$, and boil the sample for $5 \mathrm{~min}$.

14. Analyze the pull-down product by immunoblootting with anti-pan-Ras antibodies (see Note 22) (Fig. 5a).

\section{Time-lapse Imaging of Ras Activation in Response to Global Chemoattractant Stimulation}

1. Prepare chemotaxis-competent cells expressing GFP-RBD-Raf1 (see Note 23).

2. Resuspend cells with $\mathrm{DB}$ at $1 \times 10^{7}$ cells $/ \mathrm{mL}$. Place $360 \mu \mathrm{L}\left(\sim 4 \times 10^{6}\right.$ cells $)$ into one well of a 8-well chambered coverglass. Allow the cells to adhere for $10 \mathrm{~min}$.

3. Place the chamber on a fluorescnce microscope.

4. Capture images using a $40 \times$ objectives every $1 \mathrm{sec}($ see Note 24$)$.

5. Stimulate Ras activation with $40 \mu \mathrm{L} 10 \mu \mathrm{M}$ cAMP (see Note 25) (Fig. 5b).

\section{References}

1. Kae H, Lim CJ, Spiegelman GB, Weeks G. Chemoattractant-induced Ras activation during Dictyostelium aggregation. EMBO Rep. 2004; 5:602-606. [PubMed: 15143344]

2. Parent CA, Devreotes PN. Molecular genetics of signal transduction in Dictyostelium. Annu Rev Biochem. 1996; 65:411-440. [PubMed: 8811185]

3. Janetopoulos C, Jin T, Devreotes P. Receptor-mediated activation of heterotrimeric G-proteins in living cells. Science. 2001; 291:2408-2411. [PubMed: 11264536]

\footnotetext{
22 12-15\% SDS polyacrylamide gel is ideal for separating Ras proteins. The Ras10 antibody detects several Dictyostelium Ras isoforms.

23 For stable expression of GFP-RBD-Raf1, $20 \mu \mathrm{g} / \mathrm{mL} \mathrm{G} 418$ is used.

24 Adjust exposure time and frequency to minimize photobleaching.

25 Add cAMP carefully into the chamber to avoid disturbing the attached cells. Ras activation peaks at about 5 sec after stimulation.
} 
4. Xu X, Meier-Schellersheim M, Jiao X, Nelson LE, Jin T. Quantitative imaging of single live cells reveals spatiotemporal dynamics of multistep signaling events of chemoattractant gradient sensing in Dictyostelium. Mol Biol Cell. 2005; 16:676-688. [PubMed: 15563608]

5. Parent CA, Blacklock BJ, Froehlich WM, Murphy DB, Devreotes PN. G protein signaling events are activated at the leading edge of chemotactic cells. Cell. 1998; 95:81-91. [PubMed: 9778249]

6. Meili R, Ellsworth C, Lee S, Reddy TB, Ma H, Firtel RA. Chemoattractant-mediated transient activation and membrane localization of $\mathrm{Akt} / \mathrm{PKB}$ is required for efficient chemotaxis to cAMP in Dictyostelium. Embo J. 1999; 18:2092-2105. [PubMed: 10205164]

7. Funamoto S, Milan K, Meili R, Firtel RA. Role of phosphatidylinositol 3' kinase and a downstream pleckstrin homology domain-containing protein in controlling chemotaxis in dictyostelium. J Cell Biol. 2001; 153:795-810. [PubMed: 11352940]

8. Funamoto S, Meili R, Lee S, Parry L, Firtel RA. Spatial and temporal regulation of 3phosphoinositides by PI 3-kinase and PTEN mediates chemotaxis. Cell. 2002; 109:611-623. [PubMed: 12062104]

9. Iijima M, Devreotes P. Tumor suppressor PTEN mediates sensing of chemoattractant gradients. Cell. 2002; 109:599-610. [PubMed: 12062103]

10. Iijima M, Huang YE, Luo HR, Vazquez F, Devreotes PN. Novel mechanism of PTEN regulation by its phosphatidylinositol 4,5-bisphosphate binding motif is critical for chemotaxis. J Biol Chem. 2004; 279:16606-16613. [PubMed: 14764604]

11. Huang YE, Iijima M, Parent CA, Funamoto S, Firtel RA, Devreotes P. Receptor-mediated regulation of PI3Ks confines PI(3,4,5)P3 to the leading edge of chemotaxing cells. Mol Biol Cell. 2003; 14:1913-1922. [PubMed: 12802064]

12. Meili R, Ellsworth C, Firtel RA. A novel Akt/PKB-related kinase is essential for morphogenesis in Dictyostelium. Curr Biol. 2000; 10:708-717. [PubMed: 10873800]

13. Kamimura Y, Xiong Y, Iglesias PA, Hoeller O, Bolourani P, Devreotes PN. PIP3-independent activation of TorC2 and PKB at the cell's leading edge mediates chemotaxis. Curr Biol. 2008; 18:1034-1043. [PubMed: 18635356]

14. Kamimura Y, Devreotes PN. Phosphoinositide dependent protein kinase (PDK) activity regulates PIP3-dependent and -independent protein kinase B activation and chemotaxis. J Biol Chem. 2010 in press.

15. Chen MY, Long Y, Devreotes PN. A novel cytosolic regulator, Pianissimo, is required for chemoattractant receptor and $\mathrm{G}$ protein-mediated activation of the 12 transmembrane domain adenylyl cyclase in Dictyostelium. Genes Dev. 1997; 11:3218-3231. [PubMed: 9389653]

16. Mondal S, Bakthavatsalam D, Steimle P, Gassen B, Rivero F, Noegel AA. Linking Ras to myosin function: RasGEF Q, a Dictyostelium exchange factor for RasB, affects myosin II functions. J Cell Biol. 2008; 181:747-760. [PubMed: 18504297]

17. Zhang S, Charest PG, Firtel RA. Spatiotemporal regulation of Ras activity provides directional sensing. Curr Biol. 2008; 18(20):1587-93. [PubMed: 18948008]

18. Lee S, Comer FI, Sasaki A, et al. TOR complex 2 integrates cell movement during chemotaxis and signal relay in Dictyostelium. Mol Biol Cell. 2005; 16(10):4572-83. [PubMed: 16079174] 

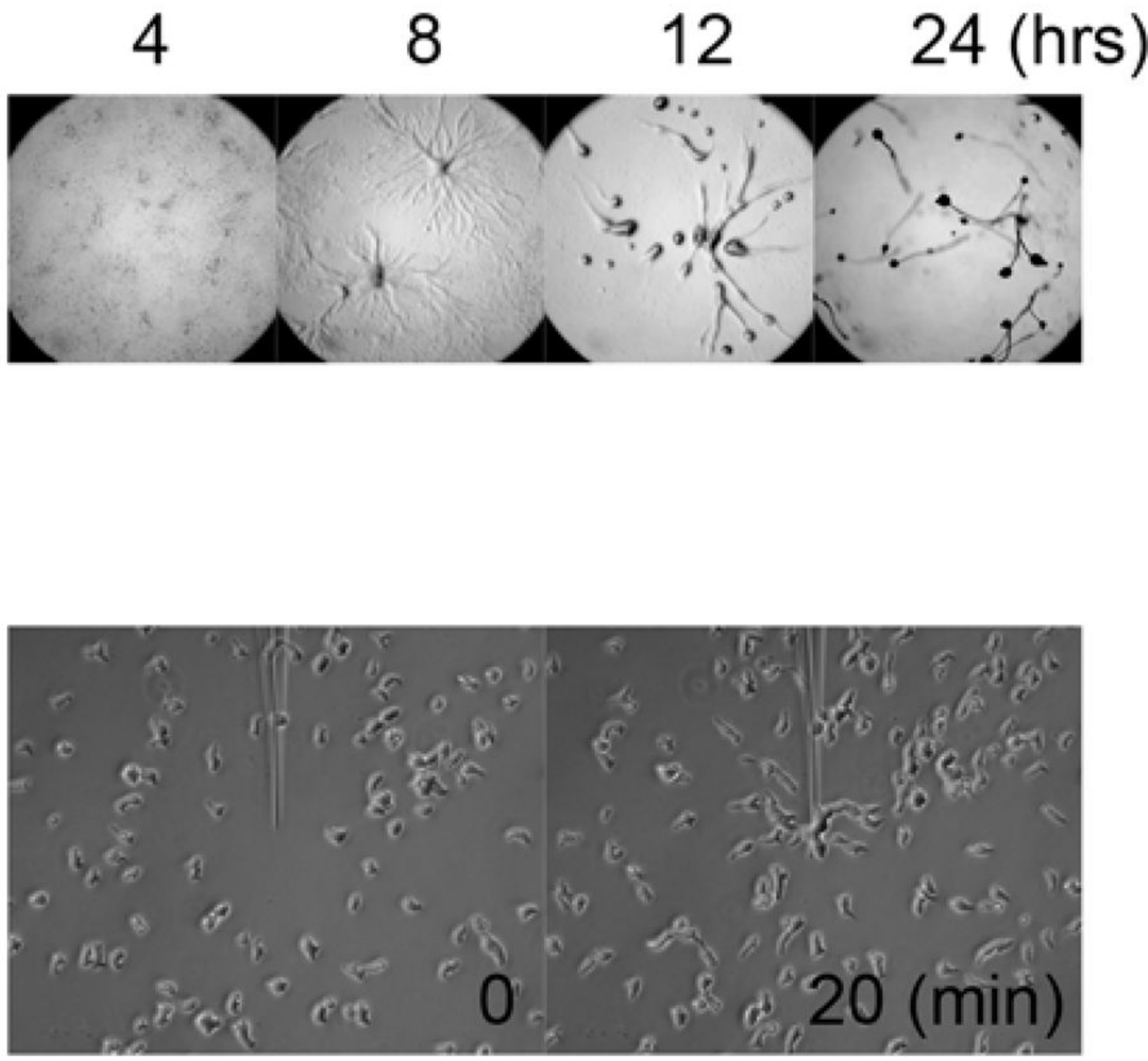

Fig. 1.

(a) Development of cells on non-nutrient agar plates. (b) Chemotaxis to a pipette filled with $1 \mu \mathrm{M}$ cAMP 


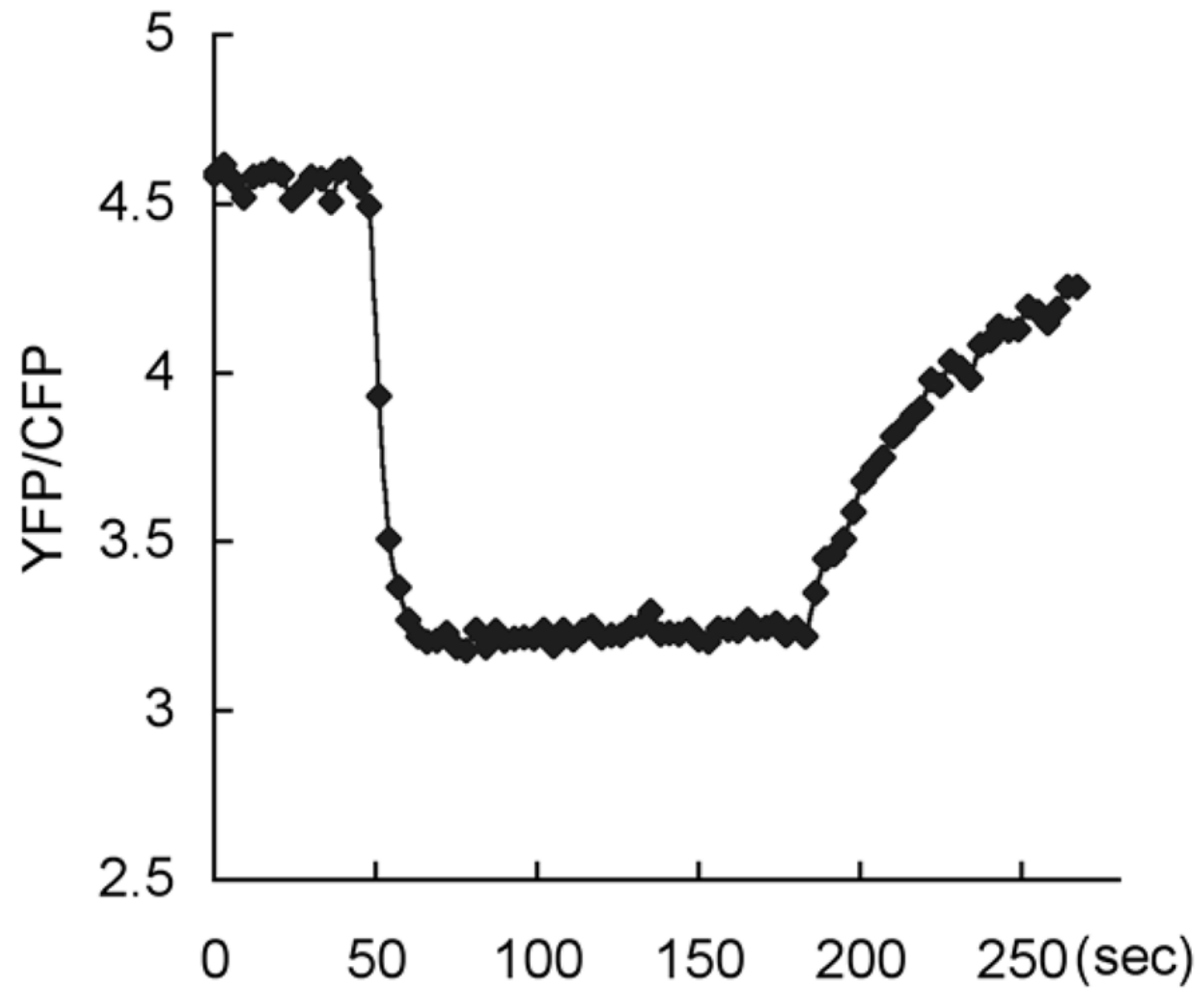

Fig. 2.

$\mathrm{G}$ protein activation upon cAMP stimulation monitored by FRET between Ga2-CFP and G $\beta$-YFP. Loss of FRET (decreased YFP:CFP ratio) was induced when a micropipette containing $10 \mu \mathrm{M}$ cAMP was introduced at $45 \mathrm{sec}$ and persisted until the micropipette was removed at $180 \mathrm{sec}$. 
a

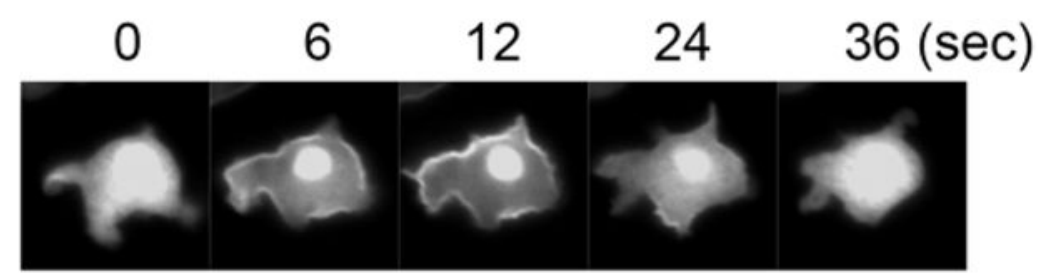

b

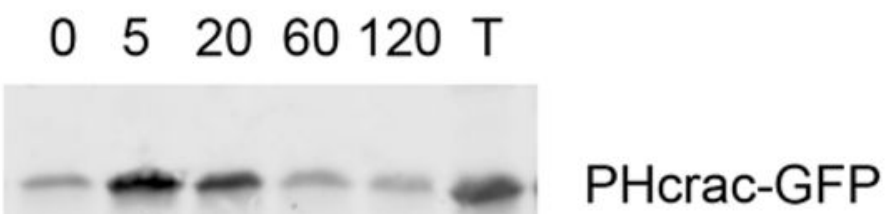

Fig. 3.

Visualization of transient $\mathrm{PIP}_{3}$ production upon uniform cAMP stimulation. Cells expressing PHcrac-GFP were examined by fluorescence microscopy (a) and immunoblotting using anti-GFP antibodies (b) after addition of $1 \mu \mathrm{M}$ cAMP. T, 20\% of input. 
a
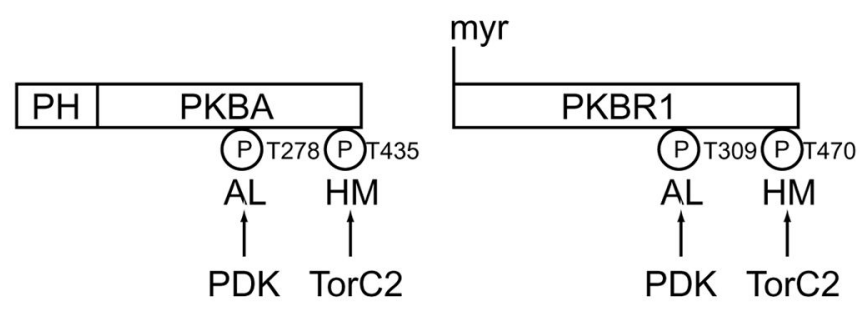

b
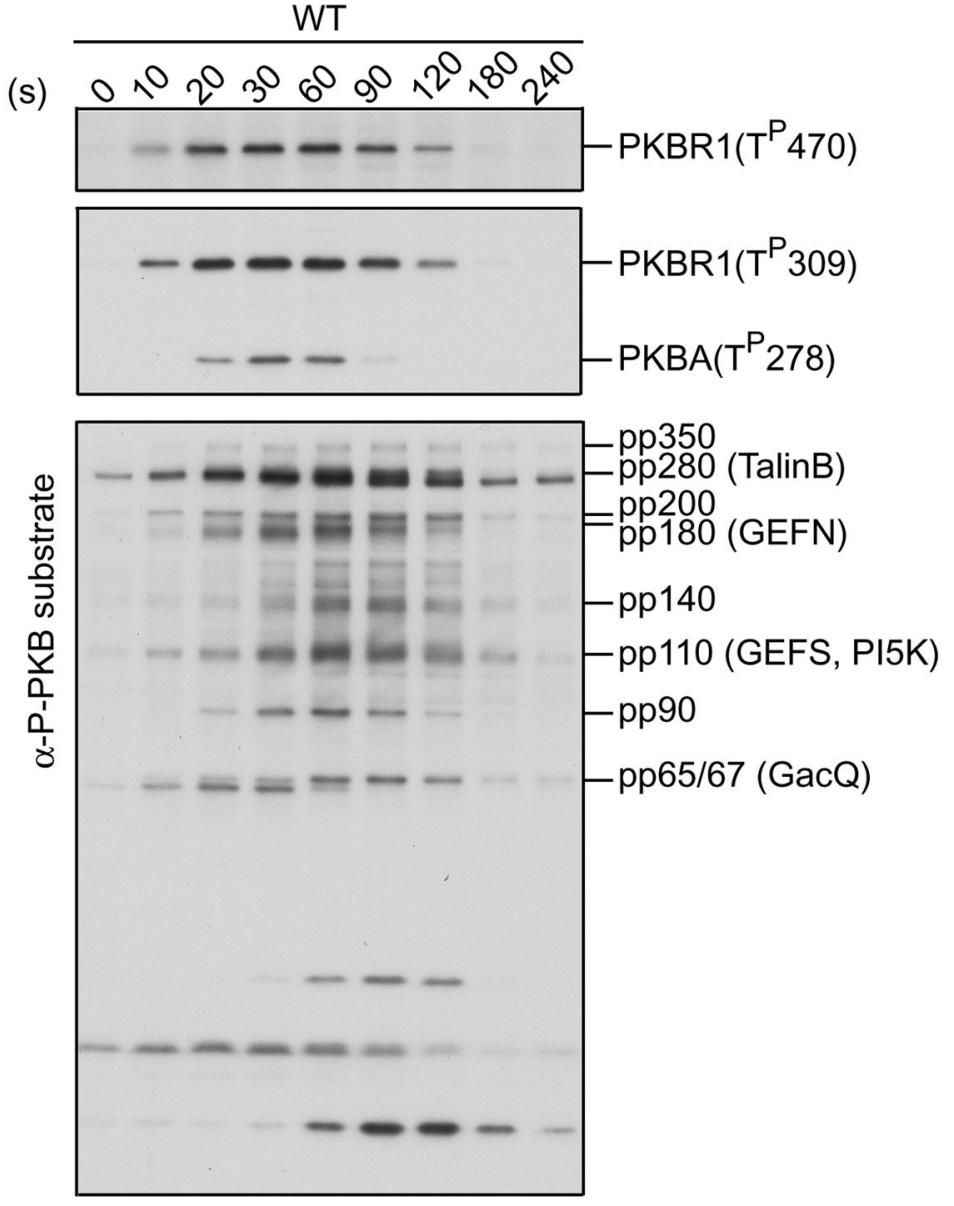

Fig. 4.

PKB activation in response to chemoattractant stimulation. (a) Schematic representation of the activation of PKBR1 and PKBA. The N-ternimus of PKBR1 is myristoylated while the $\mathrm{N}$-terminus of PKBA has a $\mathrm{PIP}_{3}$-specific PH domain. Upon cAMP stimulation, the two PKBs are activated through phosphorylation of their HMs by TorC2 and ALs by PDK. The phosphorylation sites (P) can be detected by phospho-specific antibodies. (b) Wildtype cells were stimulated with cAMP, lysed at the indicated time points, and subjected immunoblotting using antibodies against phospho HM (top panel), phospho-AL (middle panel), and phospho-substrate (bottom panel). 
a

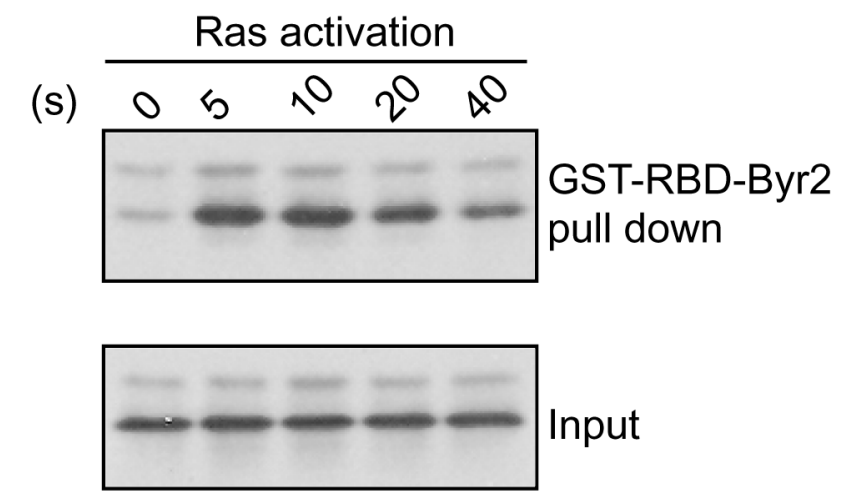

b

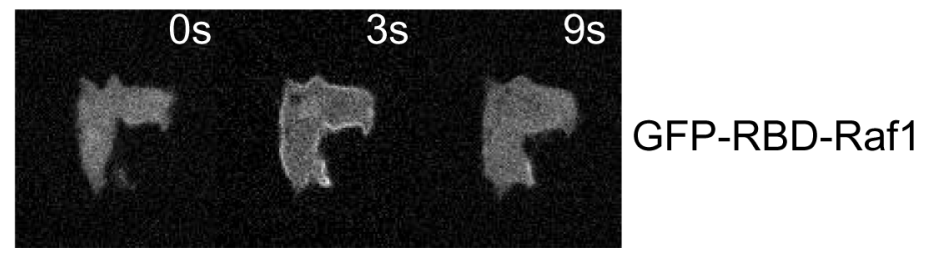

Fig. 5.

Ras activation in response to chemoattractant. (a) cAMP stimulation triggers rapid and transient activation of endogenous Ras proteins, which can be pulled down by GST-RBDByr2. (b) Fluorescent images of GFP-RBD-Raf1 in wildtype cells before and after cAMP stimulation. 